\title{
Stereotyping and Stigmatizing of Poor Whites in Today's USA
}

\author{
Concepción Parrondo Carretero
}

Department of English Philology, Faculty of Philosophy and Letters, University of Málaga, Spain

Copyright $\mathrm{C} 2017$ by authors, all rights reserved. Authors agree that this article remains permanently open access under the terms of the Creative Commons Attribution License 4.0 International License

\begin{abstract}
The stigma once imposed upon poor whites (also known by the terms of 'white trash,' 'cracker,' 'red neck,' or 'hillbilly,' among others) still lives on in a specific type of poor, notorious for their laziness, dirt-eating, propensity to criminality, sexual perversity, consanguinity, feeblemindedness, and chronic disease portability. It is through mass media communications that this group has been placed on the margins of a capitalist interest-driven market economy in the hands of the dominant whites who dictate the rules by which all members of society are to abide. It is no longer the account of the traveler or the written text what can be damaging to the public image of a social group, but a much powerful vehicle of communication that attracts large numbers and travels at the speed of light. As an image is worth a thousand words, the visual impact created by TV or the cinema has no equal. This paper aims to examine the social stereotyping and stigmatizing of poor whites (the bad type) in mass media communications through the analysis of two films (Deliverance 1972 and Monster 2003), a documentary (The Wild and Wonderful Whites of West Virginia 2009), and a reality TV series (Here Comes Honey Boo Boo 2012) to ultimately come to the realization that social stigmatizing is very much alive in the United States of the $21^{\text {st }}$ century.
\end{abstract}

Keywords Poor Whites, Poor White Trash, Stigmatizing, Hegemonic Whites, Mass Media Communications, Commodification

\section{Introduction: The Origins of the Poor Whites' Stereotyped Traits}

The concept of slavery was no novelty in the colonies but was adopted by those settlers who first arrived in the New World. Such a concept encompassed different groups not so much thought of by race as, rather, by class. Barney Warf [1] explains that enslaved classes were taken in, in colonial territories, by farmers in the region who regarded serfdom as a commodity as well as a sign of wealth. Life in the colonies was modeled after life back on the British Isles, that is to say it rested on a feudal social hierarchical system controlled by a few, but powerful, masters of the land. The colonies were rooted in a social structure where the notions of southern elite, gentility, and honor were paramount. In such state of affairs three different terms-lubber, cracker, and poor white trash-stood out among a plethora of pejorative words by which to refer to the poorest and weakest of society.

Lubbers were known to be disdainful people with no regards for industry or work, yet they were considered harmless to society. Crackers, on the other hand, referred to poor and landless free white people who had run to the west margins of the colonies. Crackers had a reputation for stealing, being ill-mannered, arrogant, treacherous, and even dangerous. They, as pointed out by Matt Wray [2], embodied a type of poor who went against the law and rebelled against the planters and landed gentry. It is in this variant of poor white crackers that term poor white trash originated. Several and distinct 'traits' defined the social category of poor white trash:

In the $19^{\text {th }}$ century, Augustus Baldwin Longstreet created Ransy Sniffle, a character which would popularize and stigmatize the figure of the poor man. Though Sniffle was a comic man notable for his poor diet, his physical deformities, his laziness, apathy, and low intelligence, what really made him standout was his habit of eating dirt. Dirt-eating was considered the mark of poor white depravity and, therefore, came to be known as the first of many traits belonging to the stigma of poor white trash.

The second trait attributed to this social category quickly spread after the Civil War, upon the emergence of a professional and industrious higher class of whites, known as the middle-class. As the middle-class could not accept the existence of poverty among them, scientists, researchers and scholars of the time concentrated their efforts on studying the social degeneracy of being poor in the lower class. Because of Elizabeth Kites's [3] work, rumor had it that social depravity and degeneration could 
spread among the general population. Such misconception led to the compulsory and involuntary sterilization of thousands of poor whites during the first half of the $20^{\text {th }}$ century.

Not happy with tagging poor whites with the label of depravity, researchers applied themselves to digging further into the condition of being poor and concluded that poor whites also suffered from feeblemindedness which quickly became an identifier of poverty. It was Henry Goddard's study [4] that launched the belief that intelligence was inherited and could be measured. Intelligence studies were performed on the poor, considered a threat to society because of their laziness, reluctance to work, propensity to criminality and disgusting habits such as dirt-eating. Science resolved that such a trait, feeblemindedness, was more noticeable in rural areas in the South of the US. Feeblemindedness and degeneration marked a very sad and misfortunate period for the poor whites of the South.

As if it could not get any worse, the epidemic of the hookworm, a disease that haunted the US in the first three decades of the $20^{\text {th }}$ century added another mark of inferiority traits to the list. Scientists' opinions over the causes and consequences of the epidemic of the hookworm was divided in two schools of thought: the eugenicists, who believed the hookworm was the cause of having been born poor white and trash; and the member doctors of the Rockefeller Sanitary Commission, who thought that the hookworm was the result of the dire conditions poor whites were forced to live under,. While the former were in favor of forced sterilization and even institutionalization, the latter proposed a sanitary campaign which included medical treatment and the teaching of healthy habits, especially in the areas of personal hygiene, good housekeeping and proper child-rearing. In such a way it was their belief that the social category of poor white trash could be remedied and solvable, being their so-called traits not inherited, but rather acquired by the environment they were living in. Whatever opinions scientists and researchers may have had as to the causes of the hookworm epidemic, the bottom line was that everybody saw the poor whites as a group made of inferior people, basically lazy, dirty, stupid and diseased. [5]

Today's poor whites' juncture has not changed much from that in the first half of the $20^{\text {th }}$ century. Poor whites are still looked down upon and harshly criticized for their lazy, apathetic, dirty and dangerous habits. The stigmatizing of the under-favored, however, no longer relies on travel accounts or published books. In this day and age, we are constantly being bombarded with opinions, stances and approaches to news and current events via faster channels of communication such as mass media and the world of the internet. This article reflects on the social stereotyping and stigmatizing of poor whites on mass media communications. In so doing, the films Deliverance (1972) and Monster (2003); the reality TV series Here
Comes Honey Boo Boo (2012) and the documentary The Wild and Wonderful Whites of West Virginia (2009) are brought to discussion in an effort to come to the realization that social stigmatizing is very much alive in the United States of the $21^{\text {st }}$ century.

\section{The Visual Arts and the Concept of Displacement}

The development of the film industry has greatly contributed to the exposure of ideas and opinions through the art of storytelling. Yet, in the beginning, films did not grant serious roles to lower classes such as poor whites. Being invisible to the film industry for years, poor whites' relevance to protagonists in movies did not occur until a few decades ago. It was in 1972 that the film Deliverance premiered in the US, causing social unrest due to the portrayal of a highly stereotyped image of poor whites that appeared in the film as savage, ignorant and inbred.

Given the deep impact that Deliverance made on audiences, one may infer that films seem to hold the power to project an image based on prejudice and stereotypes, a far more profitable economic strategy than siding with 'politically intended' causes. Indeed, the film industry and its capitalist economy on which it rests have done more harm than good to marginalized social classes, for 'telling a story' on film is much more attractive than writing it out in a book. In addition, films, TV series, or documentaries, have been turned within the market place into articles to be consumed, or, in other words, commodities. In a way, filmmaking - and, by the same token, anything related to the visual arts - as the industry that sells entertainment to audiences, disguises human and economic relations in the story in order to turn their product into a money-making proposition. As Jillian Sandell [6] states, when referring to white trash representation in film, "commodification operates, in other words, as another form of displacement $[\ldots]$ one that has a public and legitimate place in the market place."

Alongside these commercialized, commodity-building films which perpetuate misconceptions and prejudice against the less privileged classes, there have been others that expose the repression and restriction to which these groups are subjected with the aim to freely express agency and explore subjectivity; among them, it is worth mentioning The Secret Life of Bees (2008) and Beloved (1998). Because of the emergence of such films in the last thirty years, one can safely argue that film-making is as valid a venue to turn stereotypes around in order to develop a true whole identity by which to reach a broader public. In such fashion, film-making provides whites, resisting being associated with their dominant hegemonic kin, with a vehicle by which to empathize with, relate to, and even try to attract attention towards the classes in social crisis. Robyn Wiegman [7] states that in the U.S. popular public 
sphere, more specifically, in the commodified circuits of contemporary identity production, white disaffiliation takes shape as "liberal whiteness," a color-blind moral sameness whose reinvestment in 'America' rehabilitates the national narrative of democratic progress in the aftermath of social dissent and crisis.

Liberal whiteness takes full advantage of the film-making industry to portray middle and upper middle-class as the heroes of potential social crisis. Film-making is, indeed, a great opportunity for mainstream whites to come out of a compromising social situation triumphantly, while not being blamed for the neglect and abandonment that their economic apparatus may inflict in others. Today's film industry, then, serves the purpose of three distinct groups: the dominant whites, adamant on proving the inferiority of 'the other;' the non-white groups, claiming their true identity; and the "liberal whites", disaffiliated from white dominant practices, seeking a new contemporary non-racist identity. [8]

\section{Films, Documentaries and TV Shows: the "White Trash" Image}

Cornell West [9] explains that nihilism is the major threat for black survival in today's USA. In such context West provides a definition of nihilism as "the lived experience of coping with a life of horrifying meaninglessness, hopelessness, and (most important) lovelessness." This is true of the category of the poor whites (and within it, the so-called 'white trash') that went from being invisible to being portrayed in the movies as violent, sexually depraved and socially outcast creatures. This negative portrayal of the poor whites can only aggravate the feeling of hopelessness this class experiences due to lacking the necessary economic means to make it into society, I argue. As stated, poor whites started to become noticeable under the public eye in the film industry during the nineteen seventies. It is important to note that, prior to poor whites becoming the center of attention for filmmakers, TV series such as The Andy Griffith Show (1960-1968), and The Beverly Hillbillies (1962-1971) were already greatly acclaimed in the America of the fifties and sixties. These programs depicted light-hearted, watered down, comical poor white characters trying to function in a society that, condescendingly and patronizingly, allowed them to be part of.

The production of the film Deliverance (1972) marked the initiation of white trash into the industry. In it, poor whites were to show an exaggerated and hyperbolic side of their most detrimental stereotyped personality traits, seen above. Ignorance, inbreeding, excessive cruelty, violence and sexual depravation are depicted in the film. Instilling in the minds of the mainstream audience fear of and terror for rural poor whites/rednecks/white trash was only the beginning of a long mass media production on the under-favored. In the first decade of the $21^{\text {st }}$ century, stigmatization took a turn, as some films hitting the box office started to depict poor whites, though still criminals and social losers, as victims of either their tragic past or society's abuse. Under this light, Monster (2003), analyzed second in this article, is most telling. In this day and age, the market has diversified showing a myriad of films, documentaries, TV reality shows, among other mass media products, whose aim is directed to the portrayal of a poor contemptible, at times, and pitiful, at others, white class. To illustrate the point, the TV reality series Honey Boo Boo (2012-2014) and the documentary The Wild and Wonderful Whites of West Virginia (2009) are analyzed last.

In its portrayal of poor whites as evil, genetically inbred, intellectually inferior, and sexually depraved, Deliverance goes a step farther than the traditionally construed displacement generated by popular beliefs in the past. Directed by John Boorman, Oscar and Golden Globe nominee and winner of National Board of Review USA 1972 and National Film Preservation Board USA 2008, the film takes us on a trip down to the Cahulawassee River in Northern Georgia where four city slickers, all professional liberals belonging to upper middle-class white America, will have a most traumatic and violent experience with the inhospitable, clearly inferior hillbillies of the region. As the events unfold, Lewis, Ed, Bobbie, and Drew, the urban hot-shot protagonists, will slowly find out that the inhabitants of the Georgia Mountains are not at all what they had expected, a community of intellectually maimed primitive people; the hillbilly mountain people are capable of committing crimes such as rape, sodomy, and even, they would assume, murder. What started out as a pleasurable weekend getaway to be in contact with nature turned into a nightmare of survival of the fittest, of unearthing the innermost primal instincts of civilized humankind?

Annalee Newitz [10] establishes the idea that the stereotypes of good and bad are internalized during childhood. The problem, according to Newitz, arises when "we question our control over the boundaries between what we consider "good" and "bad"." Anxiety and consequently a feeling of guilt may occur when we realize that the boundaries between being good - white, and being badnon-white, are not clearly delineated. Newitz points out that as the term white is associated with the present civilization, all non-white (that is, bad) is then associated with the primitive past, and must exist, therefore, within the context of savagery and un-civilization. Thus, the misconstruction that poor whites, and among them white trash, are bad and live under savage primal conditions. [11] The racialized other, as the primitive 'bad guy' in the picture, must be contained and, if need be, suppressed for white hegemony to exist, I argue. This becomes even more necessary when the primitive bad belongs to the category of 'white trash.' The term 'white trash' 'is a complex cultural category; since it is racialized (i.e., different from 'black trash' or 'Indian trash') and classed (trash is social 
waste and detritus) allows us to understand how tightly intertwined racial and class identities actually are in the United States [...] It speaks to the hybrid and multiple natures of identities, the ways in which our selves are formed and shaped by often contradictory and conflicting relations of social power." [12]

These relations of social power often entail a constant struggle between the 'good' stereotype (hegemonic whites) and the 'bad' (the poor whites, and, in it, the white trash). Deliverance is a clear depiction of such struggle. As the protagonists get ready to set out into the wilderness they come across a physically (and why not intellectually, the film seems to imply ${ }^{1}$ ) maimed mountain boy who turns out to be a 'virtuoso' of the banjo. While the musical interchange goes on, the tone of the film turns upbeat and the initial tension built upon the arrival of the group does, indeed, wear off. But as soon as the high beat and lively rhythm of the contest end, the film's tension picks back up upon the boy's refusal to shake hands with a highly impressed Drew; the boy, then, walks away without saying a word. [13] Whether this encounter may reveal ominous of the class confrontation that is yet to come is not entirely clear. But the scene seems not to close, as the look in the boy's face will come to our minds later, when the nightmare for the city slickers starts to occur. One thing remains certain: in a scene where the city dwellers taunt and laugh at the mountain people, a crossed-eyed and dirt-poor boy proves his worth at mastering civilized practices such as music playing; civilization and primitivism look each other in the eye and, much to everyone's surprise, the primitive rebels against the civilized.

Nature unfolds as a hostile element for the intruders in God's country. The Cahulawassee River, with its treacherous rapids and meandering course, sets the stage for a most fatal outcome for the vacationers. Ready to make a rest stop, the friends get separated and while one group is still fighting the river current to reach the riverbank, the other has already made it to safe ground, only to fall prey to the rage of the local mountaineers. In a scene where primal instincts violently clash with civilization, these two civilized white men find themselves face to face with savagery. It is now the 'other' who taunts, humiliates, and attacks the dominant whites as two backwoods dwellers violently rape and sodomize one superior white in the group. Ready to attack the second one, their lives are spared when the other two friends come to their rescue by killing the primitive rapist. From this point onwards, violence dominates the course of the events. In an effort to avenge the rape of their friends, the white city slickers will become as aggressive and savage as the mountain rednecks. They killed one of the primitive perpetrators while the other managed to escape, only to take vengeance on them a

1 In the scene, one of the city slickers makes the comment: "talk about genetic deficiency." few scenes later. Frantically canoeing down the river, Drew will be shot and will fall into the river where he drowns.

The film turns into a contest in which only violence will prevail. Violence has become property, at this point, of not only the racialized other, the bad, but also of the civilized white, the good. As Annalee Newitz [14] states, "the idea that middle-class whites need to become savages to defend themselves is a perfect excuse for the middle classes to behave in outrageously cruel ways toward the lower classes." Once they have reached their destination, the group feels no longer empowered over or superior to the racialized class of the locals, but rather they have become 'their equal,' having been forced to act like them. Being killed and having killed themselves, the narrative seems, on the one hand, to justify the higher class's violent behavior as a self-defense mechanism and, on the other, to condemn the inferior class for their savagery and primitivism. Newitz explains, "if the lower classes 'bring down' the white middle class to their level, in essence they are 'asking for it' when the middle class turns savage and kills them off. Ultimately, middle-class whites, can use the hatred they inspire in lower-class whites to justify their own violence and to claim that they can't help being violent anyway $[\ldots]$ whites secure their innocence by swapping punishment and hatred back and forth between classes locked in combat with one another." [15]

The second to last scene reveals the protagonists, whose lives have changed forever, leaving the locality unscathed, though one of them has perished on this quest. Though the local sheriff remains suspicious, due to all the contradictions of their version of the story, he has no evidence to arrest them. The group is, in the end, warned not to come back: "Don't ever do nothin'like this again. Don't ever come back up here. I don't wanna see you or your friends again! I'd kinda like to see this town die peaceful." The friends do not contradict the authority but quickly drive away. It is interesting to note that the task of throwing the group out of redneck territory falls on the shoulders of a member of the law enforcement. The narrative seems to imply that leveling down to the primitive "bad" could not or should not be allowed. Under this light, there seems to be a silver lining for the socially stigmatized 'rural white trash' who has found in the local authorities an ally.

The ending of the film may be interpreted as twofold: not only is resorting to the most primitive attributes of human condition acceptable so long as your life is in peril, but also society may not render any punishment for such an act. It is in extreme danger, the danger of the presence of the other, (the bad, the white trash characters, stigmatized and portrayed as a threat to other whites) when savagery of any kind prevails. In the end, the redneck, white trashy officer of the law, who suspected foul play, has been outsmarted by these whites and, grudgingly, does have to let go. Being warned not to come back, the white supremacist gets away with their crime. Upon the 
conclusion of the story, one can only assume that middleand upper- class whites are still superior to the savage, even in the savage's own territory. It is no wonder, therefore, that the film appears to convey the message that white supremacy would not be welcome in the realm of the rural poor whites. Being pushed away from society, poor whites can only hope to be left alone, in their own world, under their own terms, as the sheriff put it in his last lines, "I'd kinda like to see this town die peaceful." I find it significant the use of the verb 'die.' It looked as though the sheriff, and at this point the spectator, knew of the underlying but ever-present power struggle between dominating whites and white trash. In such struggle, the film seems to imply, the dominating white class will always remain so, leaving the underprivileged feeling hopeless. This sense of hopelessness, the nihilism Cornell West speaks of, seems to have been internalized by the underprivileged class which, in order to defend themselves, have claimed theirs the primitive world. Yet, Deliverance leaves the spectator wondering about such fatalist white trash existence. Back home the friends have sworn secrecy to what happened in the woods. In the final scene, Ed awakes screaming from a nightmare in which a dead man's hand rises from the river. The message conveyed is thought-provoking as the ending could be interpreted either as outcome of a highly traumatic event, or, rather at a symbolic level, as the manifestation of guilt of a dominating class over inferior others. It will be up to the spectator to decide.

If the stereotype on rural poor whites as inferior to their kin still continues in today's US, so does the image of the rural poor white woman, portrayed as ugly, violent and sexually deviant. Monster (2003), [16] directed by Patty Jenkins, recounts the life of a serial killer, Aileen Wuornos, who at the age of 46 was executed by lethal injection in the State of Florida. The film tries to expose the mechanisms of oppression that mainstream whites exert against the marginalized and excluded. Belonging to a most current style of storytelling, that of confessional and/or life story, Monster denounces the tragic existence of Aileen Wuornos, a figure highly misunderstood by society. Aileen was born poor, white and female. Abandoned by her mother and raped by her grandfather, she started offering sexual favors in school at a very early age. After turning 14 years old and being raped by one of her grandfather's friends, Aileen was thrown out of her home. Already living at the margins of society and not knowing what else to do, Aileen dove into a life of prostitution, alcohol and drugs. Leaving her home state Michigan, she headed off to Florida where she would meet Tyria Moore, her future lover and confident. Openly declaring her homosexuality and with little hope in the system, Aileen went into a life of delinquency which eventuality led her to the killing of seven men who, as she claimed, raped her and put her life in danger. The film recreates Aileen's adult life in Florida while exposing her social abuse and neglect. The story focuses on the ninemonth period between 1989 and 1990, during which the character of Wuornos had a lesbian relationship with a woman named Selby (based on Wuornos's real life companion Tyria Moore). Committed to her partner, she then starts murdering her clientele in order to make money without rendering sexual services. The plot reveals Aileen Wuornos meeting Selby at a bar in Daytona Beach, FL. After falling in love, Aileen wants to lead a faithful relationship with her lover. For this to happen, Aileen will lurk the state's highways, like a predator, looking for ways to make money without jeopardizing her sexual-love life. Pinning the blame of her killing rampage on her traumatic past, the character reverses the roles of socially accepted conduct. As stated above, Wuornos transforms into the predator charging against the lust-seeking male. If prostitution for women, on the Florida highways, was conceived as much dangerous as it was punishable, it is the male who is now being put at risk. For it is Wuornos who, being hurt by her family and society, feels entitled to hunt and punish. The remnants of the $19^{\text {th }}$ century cult of 'true womanhood' imposed upon by a dominating puritan white male mentality are taken down by a (poor white lesbian) female ready to claim what was taken away from her. As Jeff Forret explains, [17] "it was since indentured servitude that poor white women have always been regarded as sexually depraved, their bodies being considered ugly, dirty, and disgusting and even well into the $20^{\text {th }}$ century the poor white female image has been construed as physically, intellectually and psychologically unappealing."

Wuornos's character, extrapolated perhaps by the director's desire to expose social locations of gender, class and race, posits a magnificent depiction of class, race and gender vindication. Representing the antithesis of subdued white femininity, Wuornos comes across as the epitome of white trash female: ugly, butch-like and dirt-poor, yet her character does come with an added bonus; she represents the psychologically deranged and sexually depraved type. Psychologically deranged as a product of a chastising, suppressing white society not able to help victims of domestic abuse; sexually depraved as her lesbian sexual tendencies denote a deviation most condemned by the mainstream whites.

The outcome suggested in the film does not differ much from the real course of events. Charlize Theron outdoes herself in the portrayal of the real Wuornos: her demeanor, both physical and psychological does mirror Aileen Wuornos almost to perfection. ${ }^{2}$ Representing the figure of the homosexual female white trash, this character is three times jeopardized in a social location with no way out. In the words of Jennifer C. James and Cynthia Wu, [18] "Wuornos may transpire as a socially disabled character, not because she may be physically impaired to be an active member of society but rather because her 'impairment'

2 Theron won seventeen awards for her performance, including Academy Award for best actress, Golden Globe for best actress and Screen Actors Guild award for outstanding leading actress. 
resides in "society's unwillingness to acknowledge circumstances, for example, poverty [...], that continue to create environmentally instigated forms of disability." Aileen's early childhood's abusive experience, her economic status and condition of woman, in addition to her sexual orientation are the unfortunate circumstances under which she formed her identity. Upon society's lack of interest in and concern for such social type, Wuornos unfolds as both unsalvageable and disposable; unsalvageable because she carries out her vindictive act against the white male by refusing to be his prey, and disposable because white trash like her have to be either contained or eliminated from society. As in Deliverance, Monster is a perfect display of the primal being strongly surfacing to lash out against the superior class/race/gender. The outcome is, however, all the more devastating. For not only does shame come down on Aileen for being dirt-poor white, but also the categories of lesbian and female will leave the protagonist with no other choice but retaliate against society. Further, Aileen's mental sanity is put to question as, in the eyes of society, she is 'mentally deranged,' a marker that might signal the 'inbred primal poor white trash' in her. Her mental state as well as the circumstances under which she finds herself drive her into a killing frenzy which, once put in motion, can only be stopped by her own disposal by society. [19]

Faithful to true events, Monster succeeds at making an impact on the spectator. Aileen Wuornos's death should not signal individual failure but ought to denounce the collective's, the director seems to imply. It is the community which, by pinning the socially stigmatized condition of poor-white homosexual female on Wuornos, fails to deliver. For Aileen Wuornos, the real woman, would rather die than continue living among the mainstream whites. During the last interview before her execution, Aileen Wuornos bitterly complained about having being made into a capitalist commodity; she stated: "You sabotaged my ass, society! [...] A raped woman got executed and it was used for books and movies and shit [...] you're an inhuman bunch of fucking living bastards and bitches." [20]

Using the image of white trash as a capitalist commodity has only reinforced the stereotypes this class has been labeled with since colonial times. These last thirty years have shown that the displacement suffered by the poor whites is still going strong. Deliverance and Monster depict part of the dark side of white trash stigma, the one that makes some shiver at the thought of poor whites being scary and dangerous. There are, however, other aspects of this socially built stereotype that have been recently brought out to public awareness as part of the great scheme of commodity-building capitalist society. In the last decade TV programs such as reality shows and documentaries have taken upon themselves to show white trash living from within. Such programs show up at the doorstep of the poor whites' home with the intention to stay. Here Comes
Honey Boo Boo (2012-2014) is a clear example of perpetuating prejudice against poor whites as an ignorant, inbred, lazy, and system-riding burden to society. [21] Set in their rural hometown of McIntyre, Georgia, this American (TLC) reality TV series follows not only the life of Alana Thompson but also her family's (her mother June, father Mike, and sisters, Lauryn, Jessica, and Anna). The program started in 2012 and came to an abrupt end in spring 2014. Alana is a beauty-pageant contestant whose life and, by default, the lives of her family, revolves around the world of beauty pageantry. Along with it, other aspects of southern rural white poor living are also shown. As episodes roll on, the viewer gets drawn into 'the nuts and bolts' of the Thompson family that very soon starts putting their values, thoughts about life, and reasons for their lifestyle out into the open. Each episode deals with an everyday life event the Thompsons have to cope with. Living in a shanty little house in the midst of a trailer park, the Thompsons consider themselves an ordinary southern family, the series suggests, whose activities include mud-bogging, special beauty-pageant diet, drinking, weed-smoking, road-kill exploitation, in-and-out-of-love relationships and teenage pregnancies.

While this family goes about their own business, the message conveyed by the eyes of the camera seems to indicate that their lives are anything but 'ordinary' as understood in the minds of the mainstream white audience. It is no wonder that the series has sparked controversy among critics, rising eye brows in those denouncing "the way that the show seems to assume that those (TLC's) viewers will look at this family and the world;" [22] others also criticized the attempt to portray the Thompsons as people to single out and badmouth stating that "none of the women or girls who participate in the show seems to hate themselves for their poverty, their weight, their less-than-urbane lifestyle, or the ways in which they diverge from the socially-acceptable beauty standard." [23] According to Megan Carpentier, this particular show focuses on the figure of the poor white female as repellent and non-attractive. Despite all, not minding their ugliness, the women of Here Comes Honey Boo Boo are not bothered by their physical appearance.

Other critics are of the opinion that Here Comes Honey Boo Boo wants to highlight poor whites' stereotypes by showing the audience a family portrayed as "a horde of lice-picking, lard-eating, nose-thumbing hooligans south of Mason-Dixie line." [24] Indeed, while this series could have served the purpose of demystifying the concept of rural white trash, it has done just the opposite. Those reviewers who criticize it seem to vouch for poor white social justice as they think the program constitutes a mockery and a farce on poor whites' values. Those who praise it do not see a reason beyond the point of social tolerance. Yet, telling the story should function as a strategy for social awareness, I argue. In the case under analysis, however, presenting the reality of impoverished 
whites does not lessen social inequality nor does it attempt to challenge the status quo, but rather becomes the perfect argument from which to economically benefit.

Not always have mass media tried to turn inequality of the underprivileged into a capitalist commodity. Julien Nitzberg's documentary The Wild and Wonderful Whites of West Virginia (2009) [25] represents an honest attempt to raise public awareness on the dirt-poor, uneducated whites. Considered as the sequel to The Dancin' Outlaw (1991) which introduces audiences to the life of Jesco White, a tap dancer, law-breaking mountaineer, Wonderful Whites follows the life of some members of the White family while in prison. The documentary also accompanies the Whites to hospitals and rehabilitation centers while sharing their passion for drinking, pot-smoking and prescription drug abuse. Though the entire clan seems to be doomed to leading a less-than-normal marginalized lifestyle, one of its members, Poney White, manages to leave West Virginia to settle in Minnesota where he makes a living as a house painter and feels happy to have run away from Boone County, his birth place.

Yet, Poney White's case seems to be rare within the Whites clan for, as Anthony Oliver Scott [26] explains, "back there, an anthology of country standards unfolds in real life and real time: murder ballads, cheating songs and rebel hollers, with an occasional pause for fatalistic spiritual meditation. The Whites - in particular the three generations of women who are the movie's most compelling and complicated characters-are not shy in front of the camera, and their forthrightness quiets, at least temporarily, the queasy sense of exploitation that hangs around the film."

Once again, the idea of economic exploitation surfaces in the minds of critics and viewers. Nonetheless, the documentary attempts to remain non-intrusive and, above all, nonjudgmental to the Whites' actions which lead almost all of their male members to a tragic end (some get thrown in jail, awaiting sentencing; others end up being killed). As for the women in the family, they are the ones displaying great strength while holding the family together. It is worth noting the matriarchal figure of Mamie who endures the Whites' mishaps with the law and misdeeds to each other. Contrary to other TV programs, such as reality show Here Comes Honey Boo Boo, there is rarely a scene that may appear staged in The Wonderful Whites. Kirk, one of Jesco's nieces, shows true emotions when authorities end up taking her newborn away from her, after a long-drawn legal custody battle. As Christopher Long [27] states, "at the very least, the film will not allow you to dismiss them [the Whites] as caricatures." Indeed, the characters of Wonderful Whites are not social caricatures hyperbolized and censored for their life choices, but quite the contrary: they are, for the most part, genuine and heartfelt.

Regardless the mixed emotions it might spark among its viewers, The Wild and Wonderful Whites of West Virginia signals the efforts of its producers and director to open the eyes of the public opinion to a reality that lives in the backyard of modern America. It is a reality which the mainstream Anglo-Saxon public needs to not only acknowledge but pay attention to. As Christopher Long [28], reaching the final conclusion on the film, states: "I'm not sold that we should celebrate them simply because they live life by their rules (of helpless entitlement), but damned if they aren't a fascinating bunch. And the film fulfills one of the more salutary roles of a documentary: it opens a window onto a world most people will never otherwise see."

\section{Conclusions}

On the whole, the film industry and TV have taken an active role in socially stigmatizing poor whites in the past thirty years, as shown in Deliverance and Monster films, as well as in Here Comes Honey Boo Boo reality series and The Wild and Wonderful Whites of West Virginia documentary. While the above-mentioned films concentrated on the scary, primal, abhorrent and appalling side of the poor whites, the TV shows exposed a much more detrimental side to this social class: Here Comes Honey Boo Boo and The Wild and Wonderful Whites of West Virginia let audiences experience the life of the poor whites first hand, enticing them to either mocking or condemning their existence. In both media (films and TV programs) the portrayal of poor white women has not been left out; Monster is a compelling true story of a poor white female who, driven to desperation, bitterly holds society responsible for her actions; Honey Boo Boo depicts females as those whose values and convictions are as good as anybody else's, while Wonderful Whites shows them as resolute, strong members of a clan that in order to live by their own rules, need to go on despite the circumstances.

Lastly, the reflection upon the films, TV series and documentary discussed above leads us to believe that social stereotypes about the poor whites of America are yet to be demystified. Yet, mass media communications encompass a much wider scope than films, TV series or documentaries; the internet, social networking, live TV and videoconferencing, to name a few, are also products by which to rapidly transmit thoughts, opinions and ideas. The bottom line is that all of these products of mass media communications have the potential to either make a difference or perpetuate myths, popular beliefs and urban legends. More troublesome, this new modality of 'telling the story' appears to feed on those who enjoy intruding in other people's misfortunes, while turning stereotypes into commodities for lucrative purposes. It is only now and then when sincere attempts to change the public's opinion on marginalized groups do emerge. No matter their effort, however, when it comes to raising awareness on the social juncture of the poor whites, the road to taking down the 
barriers of prejudice and social stigmatization is long and a positive outcome remains yet to be seen.

\section{REFERENCES}

[1] B. Warf, "The Deep Historical Roots of White Southern Cultures of Justice," Southeastern Geographer, Vol. 47, No. 1, 92-96, 2007.

[2] M. Wray. Not Quite White. White Trash and the Boundaries of Whiteness, Duke University Press, Durham, NC, 2006.

[3] ibid. 67

[4] H. Goddard. The Halliback Family. A Study in the Hereditary, Feeblemindedness, McMillan, N.Y., 1912.

[5] M. Wray, "The Disease of Laziness," in Not Quite White. White Trash and the Boundaries of Whiteness, Duke University Press, Durham, N.C., 96-132, 2006.

[6] J. Sandell, "Telling Stories of Queer White Trash," in White Trash. Race and Class in America. Ed. By Annalee Newitz and Matt Wray, Routledge, N.Y., 211, 1997.

[7] R. Wiegman. "Whiteness Studies and The Paradox of Particularity," Boundary, Vol. 2, No. 26.3, 120, 1999.

[8] ibid. 121

[9] C. West. Race Matters, Random House, N.Y., 23, 2001.

[10] A. Newitz, "White Savagery and Humiliation," in White Trash. Race and Class in America. Ed. by Annalee Newitz and Matt Wray, Routledge, N.Y., 133, 1997.

[11] ibid. 134

[12] ibid. 4

[13] "Dueling Banjos" scene. Online Available from: https://www.youtube.com/watch?v=1tqxzWdKKu8

[14] A. Newitz, "White Savagery and Humiliation," in White Trash. Race and Class in America. Ed. by Annalee Newits and Matt Wray, Routledge, N.Y., 1997.

[15] ibid. 145
[16] Preview to the film, Online Available from: https://www.youtube.com/watch?v=vq70brIQP40

[17] J. Forret. Race Relations at the Margins: Slaves and Poor Whites in the Antebellum Southern Country Side, Louisiana State University, 184, 2006.

[18] J. James, C. Wou, “Introduction: Race, Ethnicity, Disability and Literature: Intersections and Interventions," Melus, Vol. 31, No. 3, 3-13, 2006.

[19] For more information on Wuornos, Online Available from: https://www.biography.com/people/aileen-wuornos-117357 92

[20] See Wuornos's last interview. Ted Bundy, Online Available from: https://www.youtube.com/watch?v=K6a5gmbPV98

[21] For a preview on the series, Online Available from: https://www.youtube.com/watch?v=ng6xd2txunQ

[22] J. Poniewozick, “The Morning After: Honey Boo Boo Don't Care," Time, August 9, 2012. Online Available from: http://entertainment.time.com/2012/08/09/the-morning-afte r-honey-boo-boo-dont-care/

[23] M. Carpentier, "Here Comes Honey Boo Boo's Surprising Home-Truth," The Guardian, August 13, 2012. Online Available from: https://www.theguardian.com/commentisfree/2012/aug/13/ here-comes-honeybooboo-surprising-hometruth

[24] J. Bricklin “TLC's Here Comes Honey Boo Boo' Isn't Al That Bad," Forbes, August 12, 2012. Online Available from: https:/www.forbes.com/sites/juliabricklin/2012/08/12/tlcshere-comes-honey-boo-boo-isnt-all-that-bad/\#111099f364a 6

[25] For a preview on the series, Online Available from: https://www.youtube.com/watch?v=pUIapa-U0bY

[26] A.O. Scott, "From a Clan That Lives by Its Own Rules: A Tale Made for the Movies," New York Times, May 4, 2010. Online Available from: http://www.nytimes.com/2010/05/05/movies/05wild.html?p artner=Rotten\%2520Tomatoes\&ei $=5083 \& \quad r=0$

[27] C. Long, "The Wild and Wonderful Whites of West Virginia," DVD Review, Movie Metropolis, November 6 , 2010. Online Available from: http://www.dvdtown.com/review/wild-and-wonderful-whit es-of-west-virginia-the/dvd/8588

[28] ibid November 6, 2010. 